\title{
Paperless Trade: Evaluation of the Current Situation \& towards the Integrated Single Foreign Trade Document
}

\author{
Mustafa Emre Civelek (Corresponding author) \\ Dept. of International Logistics, Istanbul Commerce University \\ Sütlüce Mahallesi, İmrahor Caddesi, No: 90, Beyoğlu 34445, İstanbul, Turkey \\ Tel: 905325770056 E-mail: ecivelek@ticaret.edu.tr
}

Nedret Seçkin

Social Sciences Institute, Istanbul Commerce University

Sütlüce Mahallesi, İmrahor Caddesi, No: 90, Beyoğlu 34445, İstanbul, Turkey

Tel: 905325770056 E-mail: nedretseckin@hotmail.com

$\begin{array}{lrr}\text { Received: Jan. 2, } 2017 & \text { Accepted: Feb. 8, } 2017 \quad \text { Published: April 1, } 2017 \\ \text { doi:10.5296/jmr.v9i2.10669 } & \text { URL: http://dx.doi.org/10.5296/jmr.v9i2.10669 }\end{array}$

\begin{abstract}
Electronic documents began to take the place of the paper documents that are being currently used in foreign trade. In this study, it is mentioned of topics such as what are electronic documents, how are they regulated and what tools are needed to have legal validity. It also covers the developments about examples of electronic documents and electronic process studies in the international field. It is expected that the number of documents used will decrease and also the complex payment methods will eliminate in the process of transition to electronic document use. As a result, it is recommended to use a single integrated foreign trade document in this study. In this way, it is predicted that foreign trade transactions can be executed through an online platform where all parties involved in foreign trade transactions will come together.
\end{abstract}

Keywords: Paperless Trade, Electronic Document, Electronic Signature, Foreign Trade 


\section{Introduction}

Foreign trade is carried out as a whole of certified activities with many different functions and features that institutions being basically distant from each other and having different economic systems, whose foreign exchange types and ways of doing business, business processes are different from each other are involved. Documents used in foreign trade transactions vary by the countries where foreign trade is carried out and by the foreign trade legislation of these countries, and the characteristics, shipping, and delivery of the product subject to trade. Documents vary which used by the business world with a variable structure. (Laryea, 2005). Variability shown by the used paper documents regarding regulation and implementation can lead to problems between commercial parties. Electronic documents target to minimize these problems caused by differences. as well as the reduction of transaction costs and the shortening of their duration (De, 2011). It is aimed to be electronically used all of the paper documents used in foreign trade. It is also desired to be solved problems that arise from differences in electronic documents to be used on a single window system (transportation documents, circulation documents, conformity documents, financial documents, insurance documents, and bills, etc.) (McMaster, 2006). But, most of the world's studies has focused on making electronic correspondence of existing paper documents. With the single window concept, it is aimed to bring these electronic documents created separately and all the parties involved in the foreign trade together and by this means to ensure continuity and coordination. (Tsen, 2011). Documents having different functions in the paper environment will be regulated $n$ the physical environment of the issuing institution and must be sent to places of use. However, in today's digital age, such a necessity has not remained. For this reason, all document functions can be combined, and the parties can run the processes by putting their electronic signatures according to job order at separate times on a single document to be edited in web page format. (Civelek et al, 2017).

\section{2. e-Documents \& e-Signature}

It may be described as a collection of objects such as texts- images created, transmitted, stored by electronic means and containing a statement of a person or institutions on a certain issue or information testifying to a subject. It must be electronically signed by the person who sent it so that the files created in different format like word, pdf, html, xml etc.may have a binding nature for the person and institutions. Approval authorities are needed that confirming their signatures and the integrity of the document and also known as the third trusted party in electronic notary so that the electronic documents may be qualified as a certificate in the legal sense. (Flaherty \& Lovato, 2014). The electronic signature is a name given the digital code added to a document sent in an electronic form and identifying the identity and authority of the sender. (Reed, 2003).

Briefly, electronic document can be defined as a file created by any computer program which it has been confirmed that the signature is accurate and the content is original by an approval authority (Civelek ve Sözer, 2003). Electronic documents are electronic records which were created in a computer environment, secured in a computer environment, signed by means of an electronic means on the date which it was created and by the person who created and 
again delivered to the receiver via electronic media.

\section{1 e-Document Efforts in Turkey}

Electronic document studies have gained speed from the enactment of electronic signature law in Turkey in 2004. The studies on e-Invoice and e-Customs draw attention especially in the field of foreign trade in Turkey. But an environment where electronic documents are integrated is not yet in question.

\subsubsection{Electronic Invoice}

E-Invoice application is the commercial invoice application which has been prepared in electronic format in accordance with the conditions specified in the law and which has been electronically delivered between the parties by being approved by means of electronic means. They are created with secure electronic tools. E-Invoice application program provides to send the institutions electronic invoices to each other and to receive electronic invoices. Furthermore, institutions that are using the application also have the possibility of archiving in electronic environment by downloading e-invoices to their computers through e-invoice application program. Thus, the e-archive is also formed. The Export Invoice can be arranged as an e-invoice. The export bill is submitted in the annex of the customs declaration as an application at customs. These invoices are necessary for the completion of the export transactions of goods. These bills can be displayed in the customs and trade ministry system (G.İ.B., 2016).

\subsubsection{Electronic Customs}

Many developing countries are now studying to modernize their customs and to move their operations to the digital environment (Wulf \& McLinden, 2005). Turkey has come a significant way in this regard. One of the most important projects within the scope of digitalization in Turkey is the e-customs project which is being carried out by the Under secretariat of Customs. Computerized Customs Activities System software has been developed, ensuring that customs procedures can be electronically done. This software was first started as an experimental application at Ataturk Airport Customs Directorate. It is used at about 58 different points in 64 customs offices. The wise consists of four parts. These parts are Summary Declaration (manifesto module), TCGB (Turkish Republic Customs Declaration) module, Integrated Tariff Module and Accounting Modules. Along with the electronic use of customs declarations, The duration of the process such as filling, transmitting, archiving the document has been shortened. (Erbaşlar \& Dokur, 2012).

\section{2 e-Document Efforts in the World}

For the purpose of being electronic for paper documents used in foreign trade in the world and of their unification on a common platform, there are projects that various institutions are developing by coming together. These projects include e-AWB, EssDoCS, and Bolero.

\subsection{1 e-AWB}

E-AWB is an airway bill regulated as e-document in the electronic environment. E-AWB 
works are still in progress, and it is expected to develop more (IATA, 2016). Legal validity problems of e-AWB which are electronically signed are solved by multilateral agreements. (FIATA\&IATA, 2013). The electronic signature law is present in many countries today, and there is no legal difference between electronic signature and wet signature in these countries. But, this problem starts when the electronic signature is used in international operations. Because the countries do not recognize the legal validity of the signing instruments provided by the certification authority outside its borders. This problem is solved by being signed a multilateral agreement by the parties which will use the system. The e-AWB project is implemented through international agreements by being mutually agreed upon by the parties. (Sas Gargo, 2016). This project aims to be an example of digitizing the documents used in international trade and using them electronically in other documents. (IATA, 2013).

\subsubsection{EssDoCS}

EssDoCS is a company that accelerates electronic commerce transactions and produces customer-oriented solutions in this regard. It is one of leading supporters of paperless trade. EssDoCS works extensively with the States and Customs Offices all over the world for the determination of deficiencies related to the electronic documents, correctly making the necessary arrangements and ensuring that standards are created. It provides consultancy services about these issues to the firms. (EssDoCS, 2016). Electronic versions of the documents such as commercial invoice, packing list and certificates of origin used in foreign trade transactions as well as electronic versions of transport documents in the EssDoCS system can be arranged. EssDoCS considers Bill of Lading as a key in transition to electronic documents because of being a negotiable title document. As the use of this document as an electronic document increases, it is thought that the other documents will be rapidly electronics. On secure online centralized platform companies can share trade documents. Companies can use document templetes. Consequently EssDoCS save time and reduce errors through simplification and authomation of the processes (EssDoCS, 2014).

\subsubsection{Bolero}

It is a limited company established under the management of SWIFT and TTclub which are financial and logistical communities in 1998. The purpose of the establishment is to produce electronic documents which may be valid in the whole world without the need for mutual information transfer agreements. Bolero communities have brought together approximately 12,500 institutions around the world (freight brokers, container fleet carriers, port business, financing establishments, etc.). Bolero International Ltd. is one of the oldest enterprises on electronic documents around the world. The most important electronic document that Bolero works on is a bill of lading used in maritime transport. The preparation, transport of the paper documents used in transport between overseas countries and being in harmony with the financing institutions are of the greatest troubles in the world. Bolero is to produce electronic documents to minimize such difficulties and even to eliminate. Bolero also attaches importance to the bill of lading. As it is known, bill of lading is valuable paper indicating the property of the goods and a valuable document that the property of the goods can be transferred through turnover. Preparation of electronic bill of lading and its use legally 
without problems are all important in this respect (Civelek \& Sözer, 2003).

\section{Simplification \& Integration}

The benefits of using e-documents are classified as reduction of costs, reduction of processing time, elimination of application differences, increase of usability, reduction of the effect of the human factor, increase of the archive costs, recording of the economy, prevention of fraud, elimination of the complexity payment methods, reduction of the number of documents, facilitating the acquisition of commercial information, increase of trade volume, predictable costs and being no longer problem of language differences. The most important of these are the elimination of complexity payment methods and the reduction of the number of documents.

\subsection{Elimination of Complex Payment Methods}

Those based on papers from the forms of payment used in foreign trade are relatively complicated. Web-based use of electronic documents will simplify the complexity of these payment methods. Even some forms of payment will completely disappear. The payment method of BPO-Bank Payment Obligation which has just started to be used nowadays can be an example of this. BPO-Bank Payment Obligation is a new alternative to payment methods in foreign trade. The BPO payment method is designed to complement existing methods being used. In some cases, electronic letter of credit is not actually a letter of credit if it is called as the letter of credit or simply "Light L/C", neither a collateral letter of credit nor bank guarantee. It is a completely new financial solution system in its own private. BPO can be likened to letter of credit for comparison purposes in order to reduce risk and ensure payment, but it is a completely different payment method from a technical aspect. BPO is a much easier and more practical payment method compared to letter of credit. While the letter of credit provides a payment undertaking to the exporter upon the physical submission of physical credit conform documents to a bank, BPO ensures a similar undertaking based solely on the submission of electronic appropriate data (Özalp, 2014). Although alternative methods have found for the letter of credit, they cannot get enough efficiency because these methods do not carry an inclusive nature for all parties in trade and still more classical documents or electronic correspondences must be circulated to the parties. (Özkan et al, 2014). To be able to make the foreign trade through commercial electronic documents sent over the Internet, the existing foreign trade payment methods should also be simplified and adapted to the electronic environment. It is unnecessary to move many detail procedures that arises from the difficulties of doing business in paper to the electronic center. It would be appropriate that single standards which will replace the simpler transaction standards and even if possible all classic payment methods are used in electronic environment. (Civelek, Uca, \& Çemberci, 2015).

\subsection{Reduction of Number of Documents}

At least 30 documents are created for the realization of a foreign trade transaction. It will be possible to combine the functions of documents used along with the development of electronic document applications. In this case, it is expected that the document integration 
will gradually evolve towards a single document. (Civelek et al., 2017). International agreements and major investments should be made for the establishment of a common system that all institutions and organizations which trade internationally will be a member. Some of the electronic certificates are valid in some countries.

Table 1. Advantage Values of Countries Passing Electronic Documentation

\begin{tabular}{lccc}
\hline Country & $\mathbf{2 0 0 6}$ & $\mathbf{2 0 1 4}$ & Decrease \\
\hline Singapore & 3 & 3 & 0 \\
\hline Hong Kong, China & 8 & 3 & -5 \\
\hline Korea Rep. & 8 & 3 & -5 \\
\hline Georgia & 15 & 4 & -11 \\
\hline Thailand & 12 & 5 & -7 \\
\hline Chinese People's Cum. & 6 & 5 & -1 \\
\hline Philippines & 8 & 7 & -1 \\
\hline Sri Lanka & 10 & 7 & -3 \\
\hline Cambodia & 11 & 9 & -2 \\
\hline Lao Dem. P. Rep. & 15 & 10 & -5 \\
\hline Kyrgyzstan & 17 & 11 & -6 \\
\hline Kazakhstan & 13 & 12 & -1 \\
\hline Tajikistan & 13 & 12 & -1 \\
\hline Uzbekistan & 15 & 14 & -1 \\
\hline Turkey & 30 & 29 & -1 \\
\hline
\end{tabular}

This is also a shortcoming. Electronic documents or certificates must have standards that can be valid in all countries. Especially the benefits that far-eastern countries have by using electronic documents can be classified as a reduction of the number of documents, time-saving and reduction of the costs per transaction.

Singapore being at the forefront with its predecessor in electronic document use proved that the most important benefit of using electronic documents is to save time. There are single window systems, paperless documents or electronic document attempts in some of the countries in the world. According to the studies made among those starting to use electronic document among the countries, the number of missing documents varies. Georgia is among the leading countries in reducing the number of documents. While arranging about 15 different document, it has reduced the number of this document to 11 between 2006 and 2014 and 4 with the increase in electronics. Countries such as Kyrgyzstan and Thailand are also among the countries that have started to reduce document numbers rapidly along with the transition to electronic documents. Information on the numerical value related to the number of missing documents of the countries starting to use electronic document among the countries are shown in Table 1. (World Bank, 2014) (Ha \& Lim, 2014). Reduction of the number of documents required for completion of a foreign trade transaction cause simplification. The most important benefits of simplification are transaction time and cost decrease. Consequently this decrease exert positive influence on economic growth. 


\subsection{Difficulties and Challenges of Intergration}

Integration of all the documents firstly need integration of all the parties involved in foreign trade transaction on a single platform. But it is difficult to establish an international coordination among these parties because a large number of entities from different countries are involved in the business processes of foreign trade transactions. There are the reliance and familiarity that have built up towards paper documents through many years. It is difficult to eliminate this reliance because the international standards for paperless trade have not been fully determined. There are differences between the paper based business processes and the business processes conducted with paperless documents.

\section{Conclusion}

In this study, sample electronic document applications in Turkey and the world have been included. It has been seen that electronic applications we use in foreign trade in Turkey are limited to customs, road and air transport documents. In this study, sample electronic document applications in Turkey and the world have been included. Documents being used in Turkey as paper; bills, transportation documents, insurance documents, financial documents, conformity documents, circulation documents and other documents and the numbers are approximately 33. If a single window system or a foreign trade platform can be created that institutions and organizations in which foreign trade transactions are conducted, are members instead of paper documents being used, the need to arrange of so many documents will disappear. There is also a decrease in the number of documents being issued after the transition to an electronic document. Examples of reduction in the number of documents are observed in countries passing to electronic documents as seen in Table 1. It is expected that all document functions will be combined with a single application in an electronic environment in the future. This process does not seem like to take place in a very short time. The establishment of an online infrastructure that can bring together all the parties involved in foreign trade transactions (customs, transport companies, insurance companies, banks, etc.) need international cooperation by countries as well as major investments. It is observed that the establishment of such cooperation is difficult.

The establishment purpose, the establishment process of the European Union and its situation for 50 years clearly show how difficult international environments are created. The length of the processes, the approval of the preparation of the contracts and, most importantly, the establishment of common rules require both time and large investments. The greatest contribution which the member countries of the European Union provide to the foreign trade system is free movement agreements. Studies of the European countries in both their rights and in unity are the preview of the presence of the new entity that will be used in future periods. These positive developments in Europe are also rapidly manifesting itself and developing in Asian countries. Various electronic documents used in Asian countries are only within the borders of the country. It will be possible to use electronic documents that can add speed to world trade with multilateral contracts to be made between countries. It is though that the increase in the use of electronic documents will positively affect the world trade volume. The most important production factor in the digital economy is information, and the 
most important channel of information is the internet. So when the internet is considered as a factor of production, it must take its place in the front row in the scope of foreign trade.

Seen that positive and promising studies have been carried out when the studies done for Turkey are examined. Preparation of customs declarations on electronic systems as "e-declarations" and the transmission to authorized institutions via electronic systems constitute a positive working example for foreign trade. It is observed that new studies are being carried out on the documents used in foreign trade.

As a result, an analysis of the current situation has been made in this study, and it has been tried to be highlighted the need to reduce the number of documents as well as being electronic documents as a roadmap for the future. If an environment in which different countries are parties and an electronic document transfer can be created, labor and time can be used more efficiently, as well as the increase in global trade volume. The combination of document functions and the reduction of the number of documents instead of using electronic equivalents of existing documents in this environment will be more appropriate. It will open the front of the way to single document because it is unnecessary to produce more than one document in the electronic environment. Because the functions of a document which has been designed as a web page and which can be accessed by all commercial parties from all over the world can be increased as desired. A single foreign trade document may perform the functions of all documents which have been separately issued. An online platform is needed where all parties will be members to finalize the foreign trade transaction using a single electronic document. All parties involved in this process must come together on a common system so that a foreign trade transaction is carried out over the internet on a single document from the beginning to the end. As future research, studies on the legal basis of single title document can be recommended.

\section{References}

Civelek, M. E. (2009). Internet Çă̆ı Dinamikleri. İstanbul: Beta Basım.

Civelek, M. E., \& Sözer, E. G. (2003). Internet Ticareti: Yeni EkoSosyal Sistem ve Ticaret Noktaları. İstanbul: Beta Basım.

Civelek, M. E., Uca, N., \& Çemberci, M. (2015). eUCP and Electronic Commerce Investments:e-Signature and Paperless Foreign Trade. Eurasian Acadeny of Sciences Eurasian Business \& Economics Journal, 3(1), 60-70.

Civelek, M. E., Çemberci, M., Uca, N., Çelebi, Ü., \& Özalp, A. (2017). Challenges of Paperless Trade: Redesign of the Foreign Trade Process and Bundling Functions of Traditional Documents. International Business Research, 10(2), 74-81. https://doi.org/10.5539/ibr.v10n2p74

De, P. (2011). Trade Facilitation in India: An Analysis of Trade Processes and Procedures. Bangkok: ARTNeT Working Paper Series.

Erbaşlar, G., \& Dokur, Ş. (2012). Elektronik Ticaret e-ticaret. Ankara: Nobel Yayıncılık. 
EssDoCS. (2014). White Paper on adopting CargoDocs .

EssDoCS. (2016, 08 12). http://www.essdocs.com adresinden alınmıştır

FIATA \& IATA. (2013). Resolution 672 Form of Multilateral e-Air Waybill Agreement. Geneva.

Flaherty, C., \& Lovato, C. (2014). Digital signatures and the Paperless Office. Journal of Internet Law, 17(7), 3-10.

G.İ.B. (2016, 12 02). eFatura. www.efatura.gov.tr: http://www.efatura.gov.tr/efaturamevzuat.html adresinden alınmıştır

Ha, Sung Heun, \& Lim, Sang Won. (2014). The Progress of Paperless Trade in Asia and The Pacific: Enabling International Supply Chain Integration. Adb Working Paper Series on Regional Economic Integration, 13.

IATA. (2013). e-Freight Handbook v4.0. www.iata.org.

IATA. (2016). IATA: http://www.iata.org/whatwedo/cargo/e/eawb/Pages/index.aspx adresinden alınmıştır

Laryea, E. (2005). Facilitating Paperless International Trade: A Survey of Law and Policy in Asia. International Review Of Law Computers, 19(2), 121-142. https://doi.org/10.1080/13600860500131200

McMaster, J. (2006). The Evolution of Electronic Trade Facilitation: Towards a Global Single Window Trade Portal. The Electronic Journal of Information, 1-19.

Özalp, A. (2014). BPO’nun Kullanılması. İstanbul: Türkmen Kitapevi.

Özkan, Ö., Bayram, O., Karakaya, G., \& Karakaya, E. (2014). Is the Letter of Credit Losing Its Significance? A New Payment Method in International Trade Bpo/Bank Payment Obligation. International Journal of Arts and Commerce.

Reed, C. (2003). What is a Signature? The Journal of Information Law.

Sas Gargo. (2016). www.sascargo.com. http://www.sascargo.com/en/Operations/

Tsen, J. K. (2011). Ten Years Of Single Window Implementation: Lessons Learned For The Future. Global Trade Facilitation Conference, (s. 1-26).

World Bank. (2014). Doing Business Database. Available at http://www.doingbuisness.org/data/exploretopics/trading-across-borders

Wulf, L. D., \& McLinden , G. (2005). The role of Information Technology in Customs Modernization. L. D. Wulf, \& J. Sokol içinde, Customs Modernization Handbook (s. 285-310). The Worl Bank.

\section{Copyright Disclaimer}

Copyright for this article is retained by the author(s), with first publication rights granted to 
the journal.

This is an open-access article distributed under the terms and conditions of the Creative Commons Attribution license (http://creativecommons.org/licenses/by/3.0/) 